\title{
Identity and Pathogenicity of Fungi Associated with Crown and Root Rot of Dryland Winter Wheat in Azerbaijan
}

\author{
Göksel Özer, ${ }^{1, \dagger}$ Timothy C. Paulitz, ${ }^{2, \dagger}$ Mustafa Imren, ${ }^{1}$ Mehtap Alkan, ${ }^{1}$ Hafiz Muminjanov, ${ }^{3}$ and Abdelfattah A. Dababat ${ }^{4, \dagger}$ \\ ${ }^{1}$ Department of Plant Protection, Faculty of Agriculture and Natural Science, Bolu Abant Izzet Baysal University, Bolu, 14030, \\ Turkey \\ ${ }^{2}$ United States Department of Agriculture-Agricultural Research Service, Wheat Health, Genetics and Quality Research Unit, \\ Washington State University, Pullman, WA 99164-6430, U.S.A. \\ ${ }^{3}$ Food and Agriculture Organization of the United Nations, Plant Production and Protection Officer, Ankara, Turkey \\ ${ }^{4}$ International Maize and Wheat Improvement Centre (CIMMYT) P.O. Box. 39 Emek, Ankara, Turkey
}

\begin{abstract}
A comprehensive survey was performed to assess fungal populations associated with crown and root rot of wheat throughout the main wheatgrowing areas of Azerbaijan. Samples were taken from 76 fields; 630 fungal strains were isolated, identified, and evaluated for pathogenicity. The identification was conducted with morphological and molecular tools such as species-specific PCR and DNA sequencing of the internal transcribed spacer (ITS) and translation elongation factor 1- $\alpha$ (EF1- $\alpha)$ loci. The fungus found in the greatest number of fields (44) was Fusarium culmorum with 192 isolates, followed by $F$. acuminatum. Other Fusarium spp. isolates were identified: $F$. equiseti, $F$. pseudograminearum, $F$. graminearum, $F$. incarnatum, $F$. avenaceum, $F$. hostae, $F$. oxysporum, $F$. proliferatum, $F$. algeriense, and $F$. brachygibbosum.

on ITS and $E F 1-\alpha$ sequences of the isolates showed that the isolates belonging to the same species were clearly separated in the dendrogram. Pathogenicity assays revealed that $F$. culmorum, $F$. pseudograminearum, and $F$. graminearum were most aggressive; $F$. avenaceum, $F$. hostae, $F$. algeriense, $B$. sorokiniana, $C$. spicifera, and $R$. solani isolates were moderately aggressive; $C$. inaequalis, E. pedicellatum, and $N$. oryzae were weakly aggressive; and others were nonpathogenic. The result of this study exhibited the existence of a wide range of species associated with crown and root rot of wheat in Azerbaijan. Additionally, this is the first report of $F$. hostae, $F$. algeriense, $C$. spicifera, $C$. inaequalis, and $N$. ory$z a e$ as pathogens on wheat in Azerbaijan. Azerbaijan is the second country after Algeria in which $F$. algeriense was detected.
\end{abstract} Bipolaris sorokiniana, Curvularia spicifera, Exserohilum pedicellatum, Nigrospora oryzae, and Rhizoctonia spp. isolates were also identified, associated with underground parts of wheat. Phylogenetic analyses based
Keywords: Bipolaris, common root rot, Fusarium, Fusarium crown rot, pathogenicity, soilborne diseases, Triticum spp., wheat diseases,
Wheat (Triticum spp.) is the third most important crop in terms of global production, with an average annual production of almost 772 million tons in 2017, after maize and rice (FAOSTAT 2019). Bread wheat (Triticum aestivum L.) and durum wheat (T. durum Desf.) provide a major contribution to the diets of humans and livestock in Azerbaijan, with an average annual production of about 1.77 million tons in a planted area of about 596,000 ha. Much of the production is under irrigation, with winter wheat planted from October to November, with an average yield of 3.0 to $3.5 \mathrm{t} / \mathrm{ha}$. Rotation crops under irrigation include cotton, maize, and forage crops. Dryland production in areas with precipitation of $<400$ to $450 \mathrm{~mm} /$ year yield only 1.3 to $1.9 \mathrm{t} / \mathrm{ha}$. Average minimum temperature in January in the rainfed wheat production region of Gobustan is $-11.4^{\circ} \mathrm{C}$ while average maximum temperature in June is $24.8^{\circ} \mathrm{C}$. Average annual precipitation ranges from 380 to $420 \mathrm{~mm}$.

A complex of fungi attacking the crown and root tissues of wheat causes a serious problem and significant yield reductions in the major

${ }^{\dagger}$ Corresponding authors: G. Özer; gokozer@gmail.com; A. A. Dababat; a.dababat@cgiar.org; and T. Paulitz; timothy.paulitz@usda.gov

Funding: Support for this study was provided by the Food and Agriculture Organization of the United Nations, the International Maize and Wheat Improvement Center (CIMMYT), and the Research and Development Unit (BAP) of Bolu Abant Izzet Baysal University (project number 2016. 10.05.1108)

The author(s) declare no conflict of interest.

Accepted for publication 24 February 2020.

This article is in the public domain and not copyrightable. It may be freely reprinted with customary crediting of the source. The American Phytopathological Society, 2020. wheat-producing regions of the world (Bockus et al. 2010; Gonzalez and Trevathan 2000). Although most prevailing species in this complex can change yearly and regionally in dryland winter wheat production areas, several fungi have been reported in the species complex: Bipolaris sorokiniana Shoemaker (teleomorph: Cochliobolus sativus (S. Ito \& Kurib.) Drechsler ex Dastur, syn. Helminthosporium sativum Pammel, C. M. King \& Bakke), Fusarium pseudograminearum O’Donnell \& T. Aoki (teleomorph: Gibberella coronicola $\mathrm{T}$. Aoki \& O'Donnell), F. graminearum Schwabe (teleomorph: G. zeae (Schwein.) Petch), F. culmorum (Wm. G. Sm.) Sacc., $F$. avenaceum (Fr.) Sacc. (teleomorph: G. avenacea R. J. Cook), $F$. equiseti (Corda) Sacc. (teleomorph: G. intricans Wollenw.), F. oxysporum Schltdl., F. acuminatum Ellis \& Everh. (teleomorph: $G$. acuminata Wollenw.), Microdochium nivale (Fr.) Samuels \& I. C. Hallett (syn. F. nivale (Fr.) Sorauer), F. algeriense I. Laraba \& K. O'Donnell, and Rhizoctonia solani J. G. Kühn (teleomorph: Thanatephorus cucumeris (A. B. Frank) Donk) (Cook and Veseth 1991; Gonzalez and Trevathan 2000; Hill et al. 1983; Laraba et al. 2017; Moya-Elizondo et al. 2011; Paulitz et al. 2002; Smiley and Patterson 1996; Smiley et al. 2005; Tunali et al. 2008). These pathogens may exist one by one; however, they generally coincide in the same areas and even in individual plants (Paulitz et al. 2002).

B. sorokiniana, causing common root rot (CRR), is the most common species of anamorphs of Cochliobolus as a root pathogen of wheat. In addition to causing dark discoloration on lower leaf sheaths, crown, subcrown internode, and root tissues, $B$. sorokiniana causes spot blotch, seed black point, seedling blight, and head blight (Bakonyi et al. 1997). The annual yield losses caused by CRR in wheat were estimated at $5.7 \%$ in Canadian prairies and varied between 13.9 and $23.9 \%$ in Australia for a susceptible wheat cultivar (Ledingham et al. 1973; Wildermuth et al. 1992). CRR symptoms on cereals also have been determined to be caused by different species of Bipolaris and Curvularia (anamorph of Cochliobolus) such as Curvularia spicifera (Bainier) Boedijn, 
C. inaequalis (Shear) Boedijn, and B. bicolor (Mitra) Shoemaker, but less severe (Bach et al. 2003; Gonzalez and Trevathan 2000; Morejon et al. 2006).

Fusarium crown rot (FCR) is caused by numerous Fusarium spp.; however, several surveys conducted to investigate the species causing FCR have revealed that the most common and devastating species are $F$. culmorum and $F$. pseudograminearum in many wheatgrowing regions of the world (Backhouse et al. 2004; Cook 1981; Moya-Elizondo et al. 2011; Shikur Gebremariam et al. 2018; Smiley and Patterson 1996; Tunali et al. 2008). Although F. culmorum prefers lower temperatures than $F$. pseudograminearum, summer temperatures in the dryland area increase the prevalence of both pathogens (Cook 2010; Dyer et al. 2009). These species have been frequently isolated from infected plants but a complex etiology of FCR has been demonstrated by several studies (Backhouse et al. 2004; Fedel-Moen and Harris 1987; Laraba et al. 2017; Smiley and Patterson 1996).

Rhizoctonia spp. are less frequently reported as the cause of damaging cereal crown and root tissues. Rhizoctonia root rot and bare patch are caused by different anastomosis groups (AGs) of $R$. solaniAG-2-1, AG-3, AG-4, AG-5, AG-8, and AG-11 isolates-which cause lesions on crown and seminal roots of wheat plants in Canada, Turkey, and the United States (Broders et al. 2014; Jaaffar et al. 2016; Ogoshi et al. 1990; Ünal et al. 2015). A decrease in the severity and decline of Rhizoctonia root rot to negligible levels has been found in long-term cereal monocrop production (Lucas et al. 1993; MacNish 1988; Yin et al. 2013).
Little is known about the distribution and prevalence of pathogens of underground parts of winter wheat in Azerbaijan. One report showed a prevalence of 17.5 to $21.4 \%$ of root rot of wheat crops, mainly Fusarium spp. and B. sorokiniana in the wheat-growing area of Shaki City (Mehdiyev 2014). Therefore, a detailed survey was carried out with the objective of identifying the fungal pathogens responsible for crown and root rot in the major wheat production areas of the country and testing pathogenicity of isolates belonging to determined species on a susceptible wheat cultivar.

\section{Materials and Methods}

Sampling. An extensive survey was conducted to collect samples showing typical symptoms of crown and root rot from 76 winter wheat fields in the main wheat-growing regions of Azerbaijan in June 2017 (Fig. 1). Samples were taken from the wheat plants collected at the stages of near maturity and maturity and after harvest. Sample sites were selected arbitrarily with a separation distance of 7 to $10 \mathrm{~km}$. For each field, 20 to 30 tillers of wheat in a 5-ha area were randomly sampled, put in paper bags, labeled with relevant sample information, transported to the laboratory, and stored at room temperature.

Isolation and maintenance of cultures. Plants were cut about $20 \mathrm{~cm}$ above the stem base; the crown, root, and stem base tissues of each plant were rinsed with tap water for at least $15 \mathrm{~min}$ to remove soil particles adhering to the surface; and stems were examined for lesions. Small 3-cm sections of the necrotic or discolored crown, subcrown, and root tissues of the plants were surface disinfested with $1 \%$ sodium hypochlorite solution for $1 \mathrm{~min}$, triple rinsed with sterile

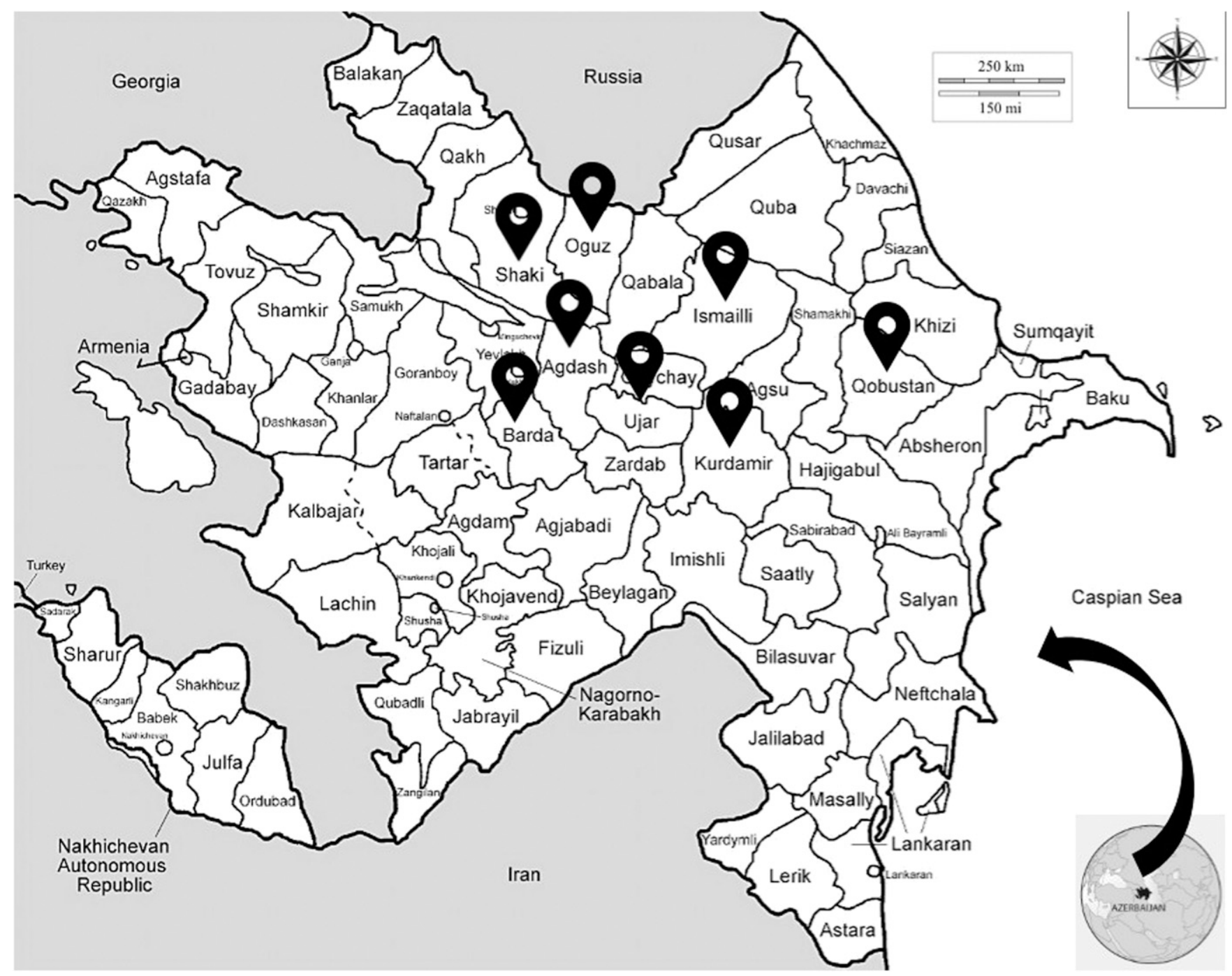

Fig. 1. Map of the Republic of Azerbaijan showing the different agro-geographical regions and sampling sites during June 2017. 
distilled water, and dried on sterilized filter paper in a laminar flow hood. Dried sections were chopped into $1-\mathrm{cm}$ lengths and placed on 1/5-strength potato dextrose agar (PDA) amended with streptomycin $(0.1 \mathrm{~g} /$ liter $)$ and chloramphenicol $(0.05 \mathrm{~g} /$ liter $)$ to eliminate bacterial contamination. Following 5 days of incubation in the dark at $20^{\circ} \mathrm{C}$, fungal colonies recovered from the sections were subcultured on new PDA plates and purified using the hyphal-tip or single-spore isolation method. To evaluate for conidia and chlamydospores, Fusarium-like colonies were also transferred to Spezieller Nährstoffarmer agar (SNA) medium and incubated at $20^{\circ} \mathrm{C}$ for 10 days (Leslie and Summerell 2006). Fungi were routinely grown on PDA at $20^{\circ} \mathrm{C}$ in the dark. All isolates were stored at $4^{\circ} \mathrm{C}$ on PDA stock plates, on filter papers in the microcentrifuge tubes at $-20^{\circ} \mathrm{C}$, and in vials containing $15 \%$ glycerol at $-80^{\circ} \mathrm{C}$ for longterm storage.

DNA extraction. A modified version of the cetyltrimethylammonium bromide (CTAB)-based method as described in the diversity arrays technology protocol (https://www.diversityarrays.com) was used to extract genomic DNA. Approximately $100 \mathrm{mg}$ of mycelia and spores of each isolate was harvested by gently scraping the surface of the culture and treated with preheated $\left(65^{\circ} \mathrm{C}\right)$ extraction-lysis buffer (2\% CTAB, $0.8 \mathrm{M} \mathrm{NaCl}, 125 \mathrm{mM}$ Tris- $\mathrm{HCl}$ [pH 8.0], $25 \mathrm{mM}$ EDTA [pH 8.0], 2\% PVP-40, $1 \%$ sarcosyl, and $0.5 \%$ sodium disulfite) for DNA extraction. The resultant DNA was dissolved in $200 \mu \mathrm{l}$ of sterile Milli-Q water. The concentration of DNA was measured by a DS-11 FX Series Spectrophotometer (Denovix Inc.) and adjusted to $50 \mathrm{ng} / \mu \mathrm{l}$ with sterile Milli-Q water for PCR assays.

Species identification. Morphological identifications of Fusarium spp. isolates based on microscopic characteristics, colony appearance, and pigmentation were performed according to Leslie and Summerell (2006) while the dematiaceous fungal isolates were identified by following the key of Ellis (1971) and Sivanesan (1987).

Species-specific PCR assays were performed to identify species using primers sets of FcOIF/FcOIR, Fp1-1/Fp1-2 (Nicholson et al. 1998), Fg16F/Fg16R (Aoki and O'Donnell 1999), and COSA_ F/COSA_R (Matusinsky et al. 2010) for F. culmorum, F. graminearum, $F$. pseudograminearum, and $B$. sorokiniana, respectively (Table 1).

To amplify the translation elongation factor $1-\alpha(E F 1-\alpha)$ gene region for Fusarium spp. and the internal transcribed spacer (ITS) region, including $5.8 \mathrm{~S}$ of ribosomal DNA (rDNA) for other fungi, primer pair EF1 (5'-ATGGGTAAGGARGACAAGAC-3') and EF2 (5'-GGARGTACCAGTSATCATG-3') described by O'Donnell et al. (1998) and primer pair ITS1 (5'-TCCGTAGGTGAACCTGCGG$\left.3^{\prime}\right)$ and ITS4 (5'-TCCTCCGCTTATTGATATGC-3') described by White et al. (1990) were used, respectively. Amplification of DNA fragments was carried out in the Arktik Thermal Cycler (Thermo Scientific) and PCRs were conducted in a 50- $\mu$ l reaction mixture containing $5 \mu \mathrm{l}$ of $10 \times$ PCR buffer, $0.4 \mu \mathrm{M}$ each primer, $50 \mathrm{ng}$ of template DNA, $0.2 \mathrm{mM}$ each dNTP, and $1.25 \mathrm{U}$ of Taq DNA Polymerase (New England BioLabs). The thermal cycler program for amplifying the ITS region was $3 \mathrm{~min}$ for an initial denaturation step at $94^{\circ} \mathrm{C}$; followed by 35 cycles with $30 \mathrm{~s}$ at $94^{\circ} \mathrm{C}, 30 \mathrm{~s}$ at $52^{\circ} \mathrm{C}$, and $1 \mathrm{~min}$ at $72^{\circ} \mathrm{C}$; and a 10 -min extension at $72^{\circ} \mathrm{C}$. To amplify the EF1- $\alpha$ locus, amplification conditions included an initial denaturation step of $3 \mathrm{~min}$ at $94^{\circ} \mathrm{C}$; followed by 35 cycles of $1 \mathrm{~min}$ at $94^{\circ} \mathrm{C}, 45 \mathrm{~s}$ at $52^{\circ} \mathrm{C}$, and $1 \mathrm{~min}$ at $72^{\circ} \mathrm{C}$; with a final extension of
10 min at $72^{\circ} \mathrm{C}$. The amplified DNA fragments were purified with Wizard SV Gel and PCR Clean-Up System (Promega Corp., Madison, WI, U.S.A.) according to the manufacturer's instructions and subjected to bidirectional direct sequencing (Macrogen, Inc., Seoul, Korea).

The resultant sequences were aligned with ClustalW, which is a multiple sequence alignment method (Thompson et al. 1994). The sequences were analyzed, and BLAST searched against GenBank (https://blast.ncbi.nlm.nih.gov/) to identify the closest available reference sequences in the complete NCBI nucleotide collection (https://blast.ncbi.nlm.nih.gov/Blast.cgi). Phylogenetic analyses of the isolates and reference isolates available in the GenBank database was performed with MEGA X software (Kumar et al. 2018) for the ITS region and EFI- $\alpha$ gene, separately. A neighbor-joining tree was constructed using the Tamura and Nei (1993) model with 1,000 bootstrap replicates.

Pathogenicity tests. To test pathogenicity, seed of cultivar Seri 82 (Triticum aestivum, bread wheat) were treated for $5 \mathrm{~min}$ in $0.5 \%$ $\mathrm{NaOCl}$ and placed in plates containing a piece of sterile filter paper saturated with water to germinate for 3 days. Plastic pots $(9 \mathrm{~cm}$ in diameter and $17 \mathrm{~cm}$ long) were filled with a mixture substrate of peat (KTS 1; Klasmann-Deilmann), sterile vermiculite, and sterile soil (1: $1: 1, \mathrm{vol} / \mathrm{vol} / \mathrm{vol}$ ) up to $5 \mathrm{~cm}$ below the top of the pots. Five seedlings were placed on the soil surface for each pot. For Fusarium spp. isolates, the inoculation was conducted with mycelial plugs removed from the margin of the actively growing PDA plate of each isolate with a sterile cork borer (10 $\mathrm{mm}$ in diameter). Plugs of each isolate were put around the wheat seedlings and covered with the mixture substrate. For assessing the pathogenicity of dematiaceous fungal isolates, the mixture substrate for covering the seedlings was inoculated with a conidial suspension of each isolate to obtain a density of 250 conidia/g (Duczek et al. 1985). The colonized wheat kernels method adapted from Demirci (1998) was performed to evaluate the pathogenicity of Rhizoctonia spp. isolates. The inoculation was carried out immediately by placing 10 colonized wheat kernels in contact with wheat seedlings and covering them with the mixture. Sterile agar plugs were used for the control treatment. There were five seeds per pot with three replications (each pot represented one replicate). Six weeks after incubation at a 12-h photoperiod and $24^{\circ} \mathrm{C}$, plants were harvested, washed, and investigated for discoloration or lesions on crown, subcrown internode, and root tissues. The symptoms were assessed by using the index system, where $1=$ no discoloration (clean), $2=$ slight discoloration $(<25 \%$ of the surface area discolored), $3=$ moderate discoloration ( 25 to $50 \%$ discolored), and $4=$ severe discoloration (at least $50 \%$ and surrounding the circumference of tissues discolored), as described by Ledingham et al. (1973). The study was repeated two times. The mean disease ratings of five isolates for each species were determined on 15 replicated seeds ( 5 seeds per pots). Scores of 1 to 2 were considered nonpathogenic or weakly pathogenic if there was a significant difference between treatment and control, scores of 2 to 3 were considered moderately pathogenic, and scores higher than 3 were considered aggressively pathogenic.

Disease severity scores obtained from the pathogenicity were analyzed for significance by analysis of variance, followed by Fisher's least significant difference test at $P=0.05$, with the Statistical Analysis System (SAS version 9.0; SAS Institute Inc.; Cary, NC, U.S.A.).

Table 1. Primers used for species-specific PCR in this study

\begin{tabular}{lllcc}
\hline Species & Primers & \multicolumn{1}{c}{ Sequences $\left(\mathbf{5}^{\prime} \mathbf{- 3}\right.$ ) } & Product size (bp) & References \\
\hline Fusarium culmorum & FcOIF & ATGGTGAACTCGTCGTGGC & 570 & Nicholson et al. 1998 \\
& FcOIR & CCCTTCTTACGCCAATCTCG & $\ldots$ & $\ldots$ \\
F. pseudograminearum & Fp1-1 & CGGGGTAGTTTCACATTTCCG & 520 & Aoki and O'Donnell 1999 \\
& Fp1-2 & GAGAATGTGATGACGACAATA & $\ldots$ & $\ldots$ \\
F. graminearum & Fg16F & CTCCGGATATGTTGCGTCAA & 420 & Nicholson et al. 1998 \\
& Fg16R & GGTAGGTATCCGACATGGCAA & $\ldots$ & $\ldots$ \\
B. sorokiniana & COSA_F & TCAAGCTGACCAAATCACCTTC & 520 & Matusinsky et al. 2010 \\
& COSA_R & CTTCTCACCAGCATCTGAATATATGA & $\ldots$ & $\ldots$ \\
\hline
\end{tabular}




\section{Results}

In total, 630 fungal strains were isolated from symptomatic wheat samples collected from 76 fields in the wheat-growing regions of Azerbaijan during the 2017 growing season. As a result of the classification of species based on morphological and molecular tools, 443 isolates of Fusarium spp., 96 of B. sorokiniana, 13 of Exserohilum pedicellatum (A. W. Henry) K .J. Leonard \& Suggs, 45 of Nigrospora oryzae (Berk. \& Broome) Petch, 13 of Rhizoctonia spp., 14 of C. spicifera, and 6 of C. inaequalis were identified (Table 2).

Among all strains, Fusarium spp. strains were found at a frequency of about $70.3 \%$. The $E F 1-\alpha$ gene sequences of 64 representative Fusarium spp. isolates ranged from 589 to 727 bp long, with identity matches of 99 to $100 \%$ with those of corresponding Fusarium spp. in the GenBank database. The sequences were deposited in the NCBI and accession numbers are shown in Figure 2. F. culmorum and $F$. acuminatum were predominant Fusarium spp., with frequencies of 43.3 and $28.2 \%$, respectively, among Fusarium spp. isolates, followed by $F$. pseudograminearum and $F$. equiseti, with frequencies of 9.7 and 7.2\%, respectively. F. hostae Geiser \& Juba, $F$. proliferatum (Matsush.) Nirenberg, F. avenaceum, F. oxysporum, $F$. graminearum, $F$. incarnatum Subraman. \& Rao, and $F$. algeriense were found less commonly, with frequencies of 2.5, 2.0, 1.6, 1.6, 1.4, 1.1 , and $0.9 \%$, respectively, whereas $F$. brachygibbosum Padwick was the least predominant (two isolates could be identified in one field from Kurdamir).

Anamorphs of Cochliobolus and the other dematiaceous fungi $E$. pedicellatum and N. oryzae were isolated from $36.8,17.1$, and $28.9 \%$ of the fields examined, respectively. BLASTn queries based on the ITS of isolates showed that the sequences of isolates were 99 to $100 \%$ identical to those of the corresponding species in the GenBank database. The sequences were deposited in the GenBank with accession numbers shown in Figure 3. Phylogenetic analyses based on ITS sequences of the isolates study and reference sequences of $B$. sorokiniana, C. spicifera, C. inaequalis, E. pedicellatum, and N. oryzae available in GenBank indicated that the isolates belonging to the same species were clearly separated in the dendrogram.

Thirteen isolates morphologically like Rhizoctonia spp. were isolated from samples representing six fields. The AG of isolates representing each field was identified by the sequencing of the ITS region of rDNA. Two isolates were determined as AG-4 HGII whereas AG2-1, AG-Fa, AG-K, and AG-G were represented by one isolate. The result of analyzing the ITS sequences of isolates using the BLAST algorithm showed that sequences were 99 to $100 \%$ identical to corresponding AG sequences in GenBank. All Rhizoctonia spp. isolates were clustered in the dendrogram with the isolates belonging the same AGs (Fig. 3).

Species-specific PCR with primers sets FcOIF/FcOIR, Fp1-1/Fp12, Fg16F/Fg16R, and COSA_F/COSA_R amplified 570, 520, 420, and $520 \mathrm{bp}$ for all strains of F. culmorum, F. graminearum, F. pseudograminearum, and B. sorokiniana, respectively (data not shown).

The pathogenicity of 73 isolates belonging to 18 fungal species and binucleate Rhizoctonia spp. isolated from winter wheat in
Azerbaijan were tested for their ability to cause disease. F. culmorum, $F$. pseudograminearum, and $F$. graminearum isolates caused severe disease on crown and root of wheat plants with means of $3.52,3.49$, and 3.23 disease severity scores, respectively, and were considered to be highly virulent species (Table 3 ). Some isolates of these species caused severe damage and resulted in the death of whole plants in some pots. $B$. sorokiniana, $F$. avenaceum, $F$. algeriense, multinucleate isolates of $R$. solani, $F$. hostae, and $C$. spicifera produced moderate disease severities, with mean scores of 2.81 , $2.72,2.45,2.38,2.20$, and 2.03, respectively. There was no difference in scoring of the mean of rot severity between three of the five isolates of $N$. oryzae and control plants $(P<0.05)$; however, two $N$. oryzae isolates were weakly virulent, causing slight discoloration on a few crowns and seminal roots of inoculated plants. Means of disease severity scores for $C$. inaequalis and $E$. pedicellatum isolates measured less than 2 (weakly virulent) but there were significant differences at $P=0.05$ from noninoculated control plants. $F$. acuminatum, F. incarnatum, F. equiseti, $F$. oxysporum, F. brachygibbosum, $F$. proliferatum, and binucleate Rhizoctonia spp. isolates exhibited no significant differences from control plants and were determined to be nonpathogenic.

\section{Discussion}

The present study identified 18 fungal species and binucleate $R h i$ zoctonia spp. isolates that were associated with diseased tissues of winter wheat. This is the first detailed survey on pathogens of underground parts of wheat in Azerbaijan. The identification of species was conducted with morphological and molecular techniques. Pathogenic characterization was employed with Seri 82 to reveal the aggressiveness of the pathogens to wheat.

Accurate identification of isolates and analyses of pathogenic variabilities within the pathogen populations provide critical information for control strategies and breeding schemes. Species identification of genera Fusarium, Bipolaris, Curvularia, Exserohilum, and Nigrospora and subspecies discrimination of Rhizoctonia spp. based on morphological characteristics are time consuming and laborious and pose difficulties such as high morphological similarities, difficulty to induce sporulation, and requirement of tester isolates to identify Rhizoctonia spp. To overcome these bottlenecks, molecular phylogenetic analyses based on ITS and EF1- $\alpha$ sequences have been widely used for the identification of different species in these genera (Berbee et al. 1999; Geiser et al. 2004; HernándezRestrepo et al. 2018; Manamgoda et al. 2012; Sharon et al. 2008; Wang et al. 2017). In this study, the sequences of ITS and EF1- $\alpha$ loci were successfully used for discrimination of the species and AGs of Rhizoctonia spp. obtained from surveyed fields. The EF1- $\alpha$ locus was used to identify Fusarium spp. obtained from diseased wheat plants in Turkey and China (Shikur Gebremariam et al. 2018; Xu et al. 2018). The sequences of ITS and the largest subunit of RNA polymerase (RPB1) sequences were necessary for the precise identification of $F$. algeriense isolates. Species-specific PCR was used for the identification of three Fusarium spp. and B. sorokiniana obtained

Table 2. Fungi associated with crown and root rot of dryland winter wheat in Azerbaijan

\begin{tabular}{|c|c|c|c|c|c|c|c|c|c|c|c|c|c|c|c|c|c|c|c|c|c|}
\hline \multirow[b]{2}{*}{ City } & \multirow[b]{2}{*}{$N^{\mathbf{y}}$} & \multicolumn{2}{|c|}{ GPS location approximated } & \multicolumn{18}{|c|}{ Fungus ${ }^{\mathbf{Z}}$} \\
\hline & & Latitude (N) & Longitude (E) & $F c$ & Fpg & $\mathrm{Fg}$ & Fac & $\mathrm{Fi}$ & Fav & $F h$ & $F e$ & Fo & $F b$ & $F p$ & Fal & $B s$ & Cs & $\mathrm{Ci}$ & $E p$ & $\boldsymbol{R}$ & No \\
\hline Qobustan & 1 & $40^{\circ} 30^{\prime}$ & $48^{\circ} 59^{\prime}$ & $0 / 0$ & $0 / 0$ & $0 / 0$ & $1 / 3$ & $0 / 0$ & $0 / 0$ & $0 / 0$ & $0 / 0$ & $0 / 0$ & $0 / 0$ & $0 / 0$ & $0 / 0$ & $1 / 7$ & $0 / 0$ & $0 / 0$ & $0 / 0$ & $0 / 0$ & $0 / 0$ \\
\hline Ismailli & 9 & $40^{\circ} 40^{\prime}-40^{\circ} 47^{\prime}$ & $47^{\circ} 57^{\prime}-48^{\circ} 32^{\prime}$ & $0 / 0$ & $0 / 0$ & $2 / 6$ & $7 / 19$ & $0 / 0$ & $0 / 0$ & $3 / 6$ & $0 / 0$ & $0 / 0$ & $0 / 0$ & $0 / 0$ & $1 / 2$ & $4 / 19$ & $0 / 0$ & $0 / 0$ & $1 / 1$ & $1 / 3$ & $3 / 5$ \\
\hline Oguz & 5 & $40^{\circ} 56^{\prime}-41^{\circ} 02^{\prime}$ & $47^{\circ} 26^{\prime}-47^{\circ} 34^{\prime}$ & $1 / 5$ & $0 / 0$ & $0 / 0$ & $3 / 9$ & $0 / 0$ & $2 / 5$ & $3 / 5$ & $0 / 0$ & $0 / 0$ & $0 / 0$ & $0 / 0$ & $1 / 2$ & $3 / 17$ & $1 / 2$ & $0 / 0$ & $1 / 3$ & $1 / 4$ & $0 / 0$ \\
\hline Shaki & 20 & $40^{\circ} 37^{\prime}-41^{\circ} 37^{\prime}$ & $47^{\circ} 07^{\prime}-47^{\circ} 26^{\prime}$ & $5 / 18$ & $1 / 5$ & $0 / 0$ & $15 / 46$ & $0 / 0$ & $0 / 0$ & $0 / 0$ & $5 / 15$ & $2 / 5$ & $0 / 0$ & $0 / 0$ & $0 / 0$ & $6 / 33$ & $4 / 10$ & $1 / 2$ & $3 / 5$ & $0 / 0$ & $3 / 7$ \\
\hline Barda & 10 & $40^{\circ} 15^{\prime}-40^{\circ} 19^{\prime}$ & $47^{\circ} 07^{\prime}-47^{\circ} 15^{\prime}$ & $10 / 43$ & $1 / 3$ & $0 / 0$ & $2 / 7$ & $2 / 4$ & $0 / 0$ & $0 / 0$ & $0 / 0$ & $1 / 2$ & $0 / 0$ & $0 / 0$ & $0 / 0$ & $0 / 0$ & $0 / 0$ & $0 / 0$ & $0 / 0$ & $2 / 4$ & $8 / 16$ \\
\hline Agdash & 2 & $40^{\circ} 16^{\prime}$ & $47^{\circ} 12^{\prime}$ & $2 / 8$ & $0 / 0$ & $0 / 0$ & $1 / 3$ & $0 / 0$ & $0 / 0$ & $0 / 0$ & $0 / 0$ & $0 / 0$ & $0 / 0$ & $0 / 0$ & $0 / 0$ & $1 / 6$ & $0 / 0$ & $2 / 4$ & $0 / 0$ & $0 / 0$ & $1 / 1$ \\
\hline Ujar & 5 & $40^{\circ} 24^{\prime}-40^{\circ} 30^{\prime}$ & $47^{\circ} 32^{\prime}-47^{\circ} 58^{\prime}$ & $2 / 9$ & $4 / 13$ & $0 / 0$ & $1 / 4$ & $0 / 0$ & $0 / 0$ & $0 / 0$ & $0 / 0$ & $0 / 0$ & $0 / 0$ & $0 / 0$ & $0 / 0$ & $0 / 0$ & $0 / 0$ & $0 / 0$ & $0 / 0$ & $0 / 0$ & $2 / 4$ \\
\hline Kurdamir & 24 & $40^{\circ} 05^{\prime}-40^{\circ} 26^{\prime}$ & $48^{\circ} 08^{\prime}-48^{\circ} 31^{\prime}$ & $24 / 109$ & $5 / 22$ & $0 / 0$ & $12 / 34$ & $1 / 1$ & $2 / 2$ & $0 / 0$ & $7 / 17$ & $0 / 0$ & $1 / 2$ & $4 / 9$ & $0 / 0$ & $4 / 14$ & $1 / 2$ & $0 / 0$ & $2 / 4$ & $2 / 2$ & $5 / 12$ \\
\hline Total & 76 & $\ldots$ & $\ldots$ & $44 / 192$ & $11 / 43$ & $2 / 6$ & $42 / 125$ & $3 / 5$ & $4 / 7$ & $6 / 11$ & $12 / 32$ & $3 / 7$ & $1 / 2$ & $4 / 9$ & $2 / 4$ & $19 / 96$ & $6 / 14$ & $3 / 6$ & $7 / 13$ & $6 / 13$ & $22 / 45$ \\
\hline
\end{tabular}

y Total number of fields.

${ }^{\mathrm{z}}$ Number of fields from which the species was obtained/number of isolates obtained. Abbreviations: Fc $=$ Fusarium culmorum, Fpg $=$ F. pseudograminearum, $F g=F$. graminearum, $F a c=F$. acuminatum, $F i=F$. incarnatum, Fav $=F$. avenaceum, Fh $=F$. hostae, Fe $=F$. equiseti, Fo $=F$. oxysporum, Fb $=F$. brachy gibbosum, $F p=F$. proliferatum, Fal $=F$. algeriense, Bs =Bipolaris sorokiniana, $C s=$ Curvularia spicifera, $C i=C$. inaequalis, Ep $=$ Exserohilum pedicellatum, $R=$ Rhizoctonia spp., and No = Nigrospora oryzae. 
in this study. The PCR with the primer sets provided definite identification for these species, which was consistent with previous reports (Abdallah-Nekache et al. 2019; Matusinsky et al. 2010; Nicholson et al. 1998).

In all, 11 of 17 fungal species determined in this study were identified as Fusarium spp. F. culmorum was found to be the most predominant species occurring on crown and root tissues of wheat with 192 isolates and was detected in $57.9 \%$ of the fields surveyed. Among the complex of Fusarium spp. associated with FCR, F. culmorum has also been reported as the most frequently isolated species in the United States (Moya-Elizondo et al. 2011; Strausbaugh et al. 2004), New Zealand (Bentley et al. 2006), eastern Australia (Burgess et al. 1981), Turkey (Tunali et al. 2008), Norway (Kosiak et al. 2003), Latvia (Bankina et al. 2013), Chile (Moya-Elizondo et al. 2015), and Algeria (Abdallah-Nekache et al. 2019). This present study was also consistent with previous observations that $F$. culmorum prefers cooler areas. We observed that $F$. acuminatum was the second most commonly isolated Fusarium sp. from below ground, with 125 isolates representing about $55.3 \%$ of the fields surveyed. The ratio of $F$. acuminatum with 125 isolates to total isolates was $19.8 \%$. This agreed with the result of a survey conducted in Turkey that $F$. acuminatum had close isolation frequency with $F$. culmorum at $14 \%$ (Shikur Gebremariam et al. 2018). F. acuminatum fungus has been found in association with $B$. sorokiniana in the root-disease complex, especially in dryland wheat production areas of Colorado and Wyoming (Fernandez et al. 1985; Gonzalez and Trevathan 2000; Hill et al. 1983; Specht and Rush 1988). F. acuminatum isolates were isolated mostly with $B$. sorokiniana in this study. Similar to $F$. culmorum, there are many reports that this fungus prefers cold weather, which is a common climatic condition in the survey area (Hall and Sutton 1998; Pettitt et al. 2003). F. pseudograminearum and F. equiseti were represented with 43 and 32 isolates, respectively. F. pseudograminearum (formerly known as $F$. graminearum group I) was isolated from $14.5 \%$ of the fields surveyed in the wheat-growing area of the

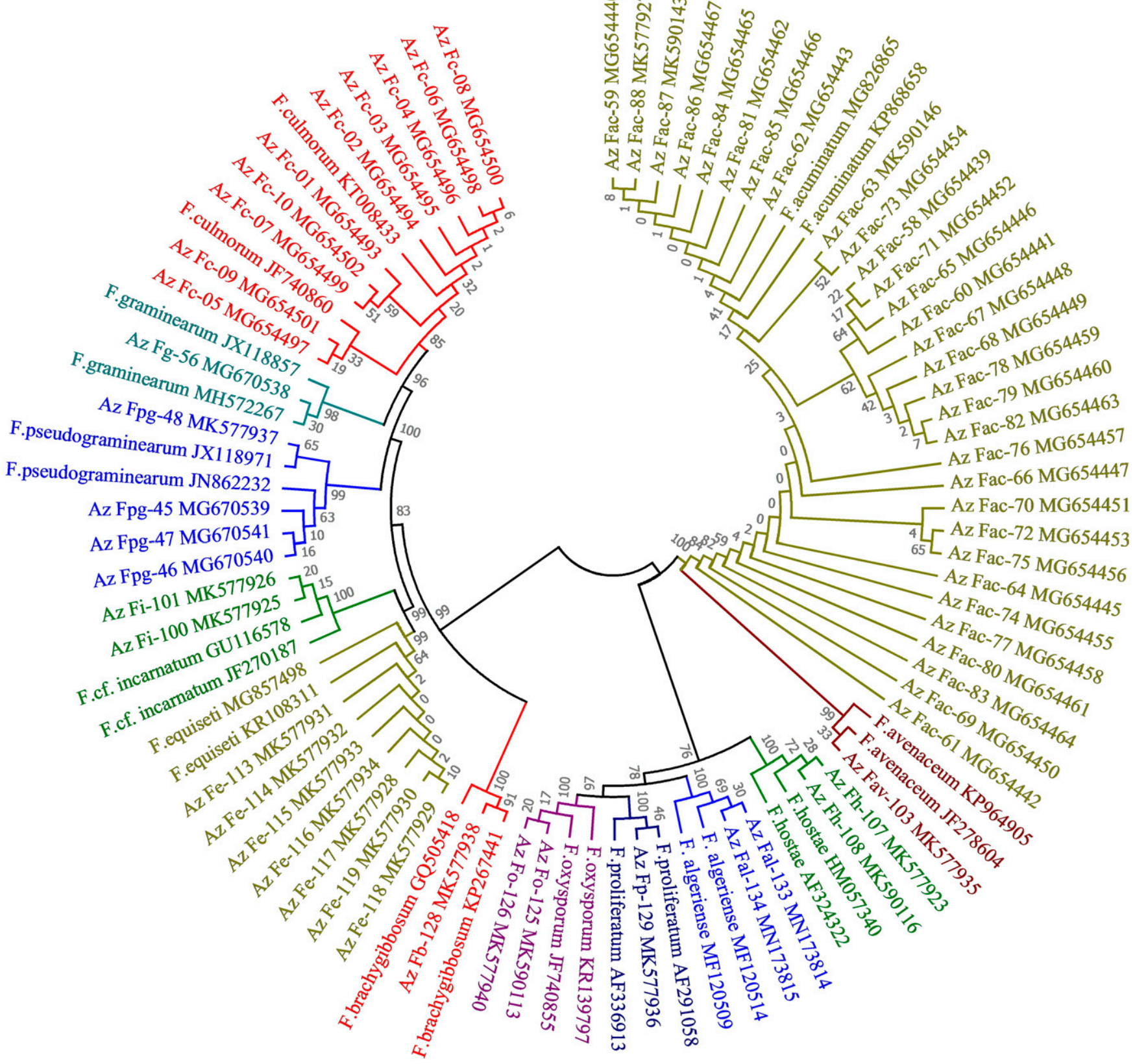

Fig. 2. Phylogeny of Fusarium spp. isolates associated with crown and root rot of winter wheat in Azerbaijan based on the translation elongation factor 1- $\alpha$ gene region (neighborjoining). Bootstrap values (percentage, based on 1,000 replications) are shown on the branches. Some representative isolates of Fusarium spp. from this study were selected for the phylogenetic tree. The remaining isolates were retrieved from NCBI database. 
country. The prevalence of this fungus has been reported to increase especially in arid and low-rainfall areas and years (Poole et al. 2013; Smiley and Patterson 1996), which explains why fungi were mostly obtained from Ujar and Kurdamir. F. equiseti has been reported as a dominant fungus associated with crown and root rot of wheat in Saskatchewan (Fernandez and Jefferson 2004), Mississippi (Gonzalez and Trevathan 2000), Italy (Rossi et al. 1995), Canada (Fernandez et al. 2014), and Turkey (Shikur Gebremariam et al. 2018), which confirms our results.

The remaining isolates belonging to seven Fusarium spp. were detected with a frequency of less than $8.1 \%$ among all isolates. They were identified in previous surveys conducted in wheat fields to determine crown and root rot pathogens (Fernandez et al. 2014; MoyaElizondo et al. 2015; Shikur Gebremariam et al. 2018; Xu et al. 2018). F. graminearum and $F$. avenaceaum were common pathogens associated with FCR after $F$. culmorum and $F$. pseudograminearum. In fact, in contrast to this study, they were exhibited as the most common species in some areas (Moya-Elizondo et al. 2015). The presence of $F$. hostae was determined at an isolate frequency of $1.75 \%$ in the limited area of only 11 fields of Ismailli and Oguz, whereas Shikur Gebremariam et al. (2018) identified the pathogen in $8.6 \%$ of the wheat fields but more commonly in the surveyed areas of Turkey. F. algeriense has been newly described as a novel crown rot pathogen of wheat while previously described in the $F$. burgessii species complex (Laraba et al. 2017). There are no reports of the existence of this pathogen outside Algeria. In this study, we determined four isolates from two fields as $F$. algeriense. Azerbaijan is the second country after Algeria in which the pathogen was detected as a pathogen causing crown rot on wheat.

Percent incidence of $B$. sorokiniana isolates in all isolates was $15.2 \%$ in this study, which conforms previous observations of this fungus being frequently isolated from crown and root tissues of winter wheat (Chen et al. 1996; Fedel-Moen and Harris 1987). C. spicifera and $C$. inaequalis, although less frequently, also were isolated as associated with CRR, which was consistent with previous reports (Gonzalez and Trevathan 2000; Hill et al. 1983; Specht and Rush 1988).

Isolates of Rhizoctonia spp. were found in $7.9 \%$ of the fields. Rhizoctonia root rot was caused by $R$. solani, occurring as lesions on the

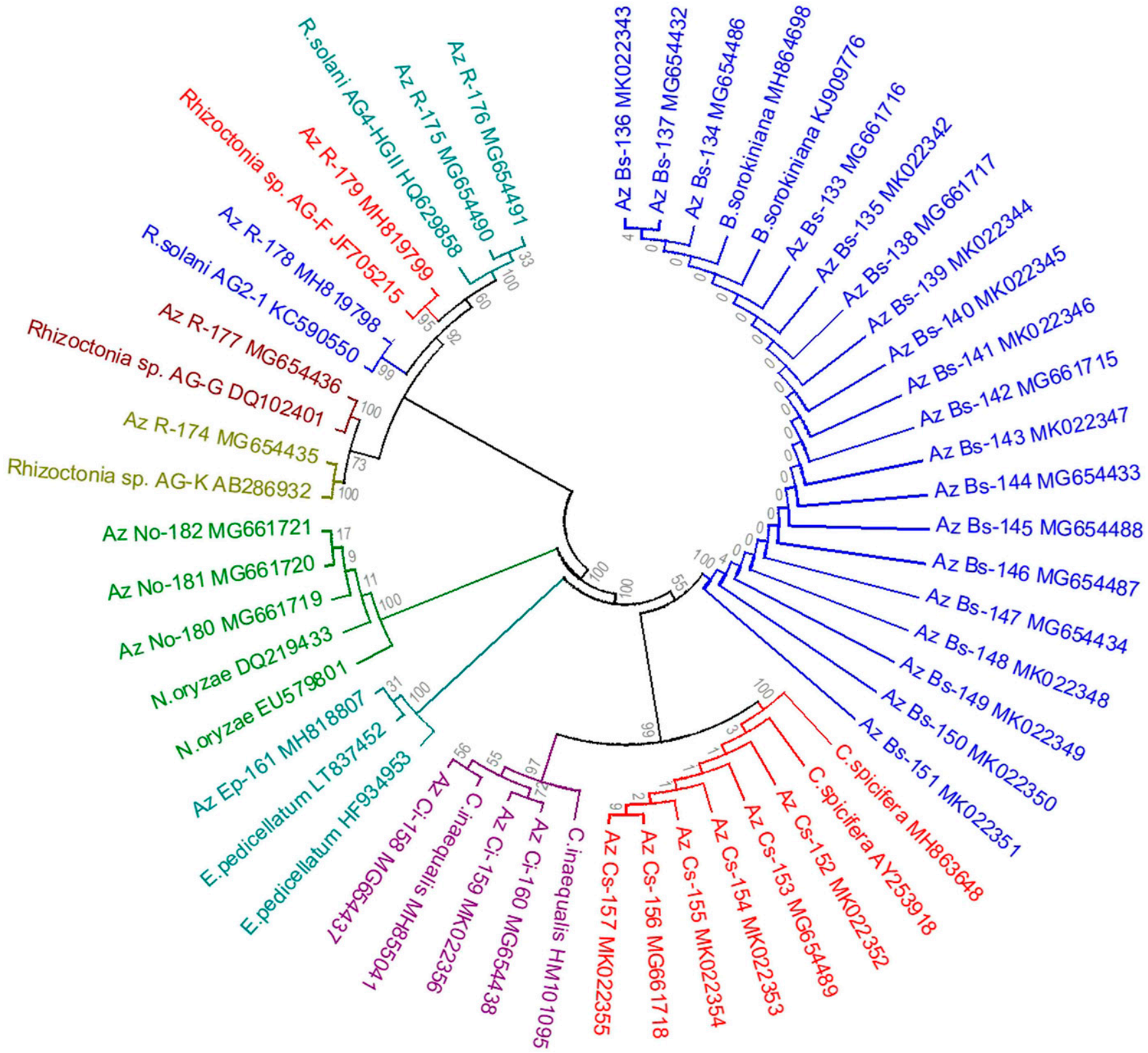

Fig. 3. Phylogeny of fungal isolates associated with crown and root rot of winter wheat in Azerbaijan based on the internal transcribed spacer region (Neighbor-joining). Bootstrap values (percentage, based on 1,000 replications) are shown on the branches. Some representative isolates from this study were selected for the phylogenetic tree. The remaining isolates were retrieved from NCBI database. 
seminal and crown roots (Paulitz et al. 2002). AG-4 HGII and AG-21 of $R$. solani were determined in this study for the first time on wheat in Azerbaijan (Özer et al. 2019b); however, the reports have been verified as AGs related to crown and root rots in wheat-growing areas in England (Brown et al. 2014) and the United States (Jaaffar et al. 2016).

E. pedicellatum, first described from wheat roots in the United States, and Nigrospora spp. were also previously isolated from discolored subcrown internodes of wheat with a lower frequency (Fernandez et al. 2014; Moya-Elizondo et al. 2015; Sivanesan 1987). Surprisingly, in our study, N. oryzae and E. pedicellatum were found to be quite common in the area, with frequencies 28.9 and $17.1 \%$ of the fields surveyed, respectively. This was the first report of $E$. pedicellatum associated with crown and root rot of wheat in Azerbaijan (Özer et al. 2019a)

Results of our seedling pathogenicity tests generally conformed to previous reports on the fungal pathogenicity of crown or root tissues of wheat seedlings. F. culmorum, F. pseudograminearum, and $F$. graminearum were the most aggressive pathogens and caused severe FCR symptoms on wheat (damping-off of seedlings and rotted crown and stem bases that resulted in the death of seedlings) while $F$. avenaceum and B. sorokiniana isolates caused similar but less severe symptoms, without the death of seedlings (Fernandez and Chen 2005; Shikur Gebremariam et al. 2018; Smiley and Patterson 1996; $\mathrm{Xu}$ et al. 2018). F. algeriense isolates caused crown rot, with discoloration of seminal roots, similar to symptoms in the publication in which the pathogen was described (Laraba et al. 2017). F. hostae isolates exhibiting moderate symptoms in the tests were found to be moderately virulent on wheat in Turkey by Shikur Gebremariam et al. (2016). F. acuminatum, F. incarnatum, F. equiseti, F. oxysporum, $F$. brachygibbosum, and $F$. proliferatum isolates in pathogenicity tests were determined to be nonpathogens based on disease severity scores not statistically significant different $(P<0.05)$ compared with control plants, which was in agreement with previous findings from pathogenicity studies on wheat (Shikur Gebremariam et al. 2018; Tunali et al. 2008; Xu et al. 2018). However, contrary to our results, isolates of $F$. acuminatum, $F$. equiseti, and $F$. oxysporum exhibiting the pathogenic reaction to wheat at different levels have been detected in some reports (Gonzalez and Trevathan 2000; Smiley and Patterson 1996).

C. spicifera strains were moderately or weakly virulent on wheat, with discoloration of the crown and seminal roots of seedlings but less severe than symptoms caused by $B$. sorokiniana, which was similar to the findings of Gonzalez and Trevathan (2000). Although no reports suggested that $C$. inaequalis caused significant damage to wheat, studies demonstrated that disease severity was considerably enhanced over single inoculations with $F$. culmorum and B. sorokiniana if combined with $C$. inaequalis (Fedel-Moen and Harris 1987).

E. pedicellatum strains and two $N$. oryzae strains were weakly pathogenic on wheat in this study while three $N$. oryzae isolates were nonpathogens. Nigrospora spp. isolates have been reported to be similar in this study: sometimes saprophytic and nonpathogenic and sometimes weakly pathogenic on wheat (Eken et al. 2016). E. pedicellatum was reported to be associated with dark-brown lesions on roots and root rot of wheat and maize (Sivanesan 1987).

$R$. solani isolates belonging to AG-4 and AG-2-1 were reported as pathogenic to wheat while binucleate strains of Rhizoctonia spp. were found to be nonpathogens (Demirci 1998). Our result supported these findings; AG-4 HGII strains caused rot, discoloration, and lesions on crown, subcrown internode, and root tissues while strain AG-2-1 was moderately virulent, causing only discoloration.

This is the first comprehensive survey to identify fungal species associated with crown and root rot of wheat conducted in the main wheat-growing regions of Azerbaijan. In the current study, the fungal species were assessed at the species level using morphological and molecular tools such as species-specific PCR and DNA sequencing of ITS and $E F-1 \alpha$ loci. No similar extensive survey was performed on fungal populations associated with wheat previously done in Azerbaijan with which we could compare these results. The FCR pathogen $F$. culmorum was the most frequently isolated and the most aggressive fungus among all species. $F$. pseudograminearum and $F$. graminearum, found at relatively lower frequencies, caused serious FCR symptoms. $F$. hostae and $F$. algeriense were first reported as moderately pathogenic on wheat in Azerbaijan. B. sorokiniana and other Cochliobolus anamorphs were found to be related to CRR. Although $C$. spicifera and $C$. inaequalis caused less severe symptoms

Table 3. Pathogenicity of fungi isolated from winter wheat in Azerbaijan

\begin{tabular}{|c|c|c|c|c|c|c|c|c|}
\hline \multirow[b]{2}{*}{ Fungus ${ }^{w}$} & \multicolumn{5}{|c|}{ Isolate $^{x}$} & \multirow[b]{2}{*}{ Control } & \multirow[b]{2}{*}{$\mathrm{LSD}_{\mathbf{0 . 0 5}}$} & \multirow[b]{2}{*}{ Mean } \\
\hline & 1 & 2 & 3 & 4 & 5 & & & \\
\hline$F c$ & $3.80 \mathrm{a}$ & $3.63 \mathrm{a}$ & $3.57 \mathrm{ab}$ & $3.33 \mathrm{bc}$ & $3.27 \mathrm{c}$ & $1.14 \mathrm{~d}$ & 0.25 & 3.52 \\
\hline Fpg & $3.77 \mathrm{a}$ & $3.70 \mathrm{a}$ & $3.40 \mathrm{~b}$ & $3.33 \mathrm{~b}$ & $3.27 \mathrm{~b}$ & $1.14 \mathrm{c}$ & 0.28 & 3.49 \\
\hline $\mathrm{Fg}$ & $3.33 \mathrm{a}$ & $3.13 \mathrm{a}$ & $\ldots$ & $\ldots$ & $\ldots$ & $1.14 \mathrm{~b}$ & 0.22 & 3.23 \\
\hline$F a c^{\mathrm{y}}$ & 1.43 & 1.40 & 1.40 & 1.37 & 1.17 & 1.14 & 0.37 & 1.35 \\
\hline$F i^{\mathrm{y}}$ & 1.23 & 1.10 & 1.06 & $\ldots$ & $\ldots$ & 1.14 & 0.31 & 1.13 \\
\hline Fav & $2.97 \mathrm{a}$ & $2.87 \mathrm{a}$ & $2.67 \mathrm{ab}$ & $2.37 \mathrm{~b}$ & $\ldots$ & $1.14 \mathrm{c}$ & 0.37 & 2.72 \\
\hline$F h$ & $2.33 \mathrm{a}$ & $2.27 \mathrm{ab}$ & $2.23 \mathrm{ab}$ & $2.17 \mathrm{ab}$ & $2.00 \mathrm{~b}$ & $1.14 \mathrm{c}$ & 0.27 & 2.20 \\
\hline$F e^{\mathrm{y}}$ & 1.30 & 1.23 & 1.21 & 1.20 & 1.17 & 1.14 & 0.20 & 1.22 \\
\hline$F o^{\mathrm{y}}$ & 1.33 & 1.30 & 1.20 & $\ldots$ & $\ldots$ & 1.14 & 0.27 & 1.28 \\
\hline$F b^{\mathrm{y}}$ & 1.10 & $\ldots$ & & $\ldots$ & $\ldots$ & 1.14 & 0.30 & 1.10 \\
\hline$F p^{\mathrm{y}}$ & 1.40 & 1.40 & 1.36 & 1.33 & $\ldots$ & 1.14 & 0.35 & 1.38 \\
\hline Fal & $2.53 \mathrm{a}$ & $2.37 \mathrm{a}$ & $\ldots$ & $\ldots$ & $\ldots$ & $1.14 \mathrm{~b}$ & 0.41 & 2.45 \\
\hline Bs & $3.15 \mathrm{a}$ & $3.13 \mathrm{a}$ & $2.93 \mathrm{ab}$ & $2.50 \mathrm{ab}$ & $2.36 \mathrm{~b}$ & $1.14 \mathrm{c}$ & 0.61 & 2.81 \\
\hline Cs & $2.29 \mathrm{a}$ & $2.15 \mathrm{ab}$ & $2.09 \mathrm{abc}$ & $1.91 \mathrm{bc}$ & $1.75 \mathrm{c}$ & $1.14 \mathrm{~d}$ & 0.35 & 2.03 \\
\hline$C i$ & $1.56 \mathrm{a}$ & $1.48 \mathrm{a}$ & $1.41 \mathrm{a}$ & $\ldots$ & $\ldots$ & $1.14 \mathrm{~b}$ & 0.20 & 1.48 \\
\hline$E p$ & $2.13 \mathrm{a}$ & $1.90 \mathrm{a}$ & $1.46 \mathrm{~b}$ & $1.43 \mathrm{bc}$ & $1.40 \mathrm{bc}$ & $1.14 \mathrm{c}$ & 0.29 & 1.66 \\
\hline$R(b n)^{\mathrm{y}}$ & $1.03(\mathrm{~A})^{\mathrm{z}}$ & $1.16(\mathrm{Fa})^{\mathrm{z}}$ & $1.20(\mathrm{~K})^{\mathrm{z}}$ & $\ldots$ & $\ldots$ & 1.14 & 0.23 & 1.13 \\
\hline$R(m n)$ & $2.60 \mathrm{a}(4)^{\mathrm{z}}$ & $2.53 b(4)^{z}$ & $2.03 \mathrm{~b}(2)^{\mathrm{z}}$ & $\ldots$ & $\ldots$ & $1.14 \mathrm{c}$ & 0.37 & 2.38 \\
\hline No & $1.80 \mathrm{a}$ & $1.77 \mathrm{a}$ & $1.40 \mathrm{~b}$ & $1.33 \mathrm{~b}$ & $1.30 \mathrm{~b}$ & $1.14 \mathrm{~b}$ & 0.37 & 1.52 \\
\hline
\end{tabular}

w Abbreviations: $F c=$ Fusarium culmorum, $F p g=F$. pseudograminearum, $F g=F$. graminearum, $F a c=F$. acuminatum, $F i=F$. incarnatum, Fav $=F$. avenaceum, $F h=F$. hostae, $F e=F$. equiseti, $F o=F$. oxysporum, $F b=F$. brachygibbosum, $F p=F$. proliferatum, Fal $=F$. algeriense, Bs $=B i p o l a r i s ~ s o r o k i n i a n a, C s=$ Curvularia spicifera, $\mathrm{C} i=\mathrm{C}$. inaequalis, Ep $=$ Exserohilum pedicellatum, $R=$ Rhizoctonia $\mathrm{spp}$. $(\mathrm{bn}=$ binucleate and $m n=$ multinucleate $)$, and $\mathrm{No}=$ Nigrospora oryzae.

x Disease severity on 15 seedlings from pathogenicity assay based on a scale of 1 to 4 . Means within a line followed by the same letter do not differ significantly at $P=0.05$ according to Fisher's least significant difference (LSD) test.

y There was no significant difference between all isolates in the line and control plants $(P<0.05)$.

z Anastomosis group of Rhizoctonia sp. isolates. 
than B. sorokiniana, both were determined to be pathogens on wheat for the first time for Azerbaijan in this study. E. pedicellatum and $N$. oryzae strains were found to be minor threats to winter wheat but at relatively higher frequencies compared with the other previous reports, highlighting the need for further work on these species if combined the other pathogens. The results of our study provide crucial and helpful information to select resistant varieties and improve disease management strategies against the major crown and root diseases of wheat in Azerbaijan. Further investigation is needed to understand their potential distribution and impact on the wheat crop.

\section{Acknowledgments}

We thank V. Bashirov (National Project Management Consultant, FAO, and Azerbaijan) for their tremendous efforts during the project period; our colleagues A. Gasimov, J. Guliyev, T. Shamiyev, G. Ahmadova, and S. Khalilova for their support during the project; and T. Mehdiyev, M. Huseinov, N. Bakhshaliev, A. Akif, J. Talai, K. Aslanova, and A. Jahangirov in the survey's regions for providing invaluable support. The authors would like to thank the Research and Development Unit (BAP) of Bolu Abant Izzet Baysal University (Project no: 2016.10.05.1108) for funding this study. Thanks go to CIMMYT especially CRP-Wheat for the great support to this study.

\section{Literature Cited}

Abdallah-Nekache, N., Laraba, I., Ducos, C., Barreau, C., Bouznad, Z., and Boureghda, H. 2019. Occurrence of Fusarium head blight and Fusarium crown rot in Algerian wheat: Identification of associated species and assessment of aggressiveness. Eur. J. Plant Pathol. 154:499-512.

Aoki, T., and O'Donnell, K. 1999. Morphological and molecular characterization of Fusarium pseudograminearum sp. nov., formerly recognized as the Group 1 population of $F$. graminearum. Mycologia 91:597-609.

Bach, E. E., Barros, B. C., and Kimati, H. 2003. Induced resistance against Bipolaris bicolor, Bipolaris sorokiniana and Drechslera tritici-repentis in wheat leaves by xantham gum and heat-inactivated conidial suspension. J. Phytopathol. 151:411-418.

Backhouse, D., Abubakar, A. A., Burgess, L. W., Dennisc, J. I., Hollaway, G. J., Wildermuth, G. B., and Henry, F. J. 2004. Survey of Fusarium species associated with crown rot of wheat and barley in eastern Australia. Australas. Plant Pathol. 33:255-261.

Bakonyi, J., Aponyi, I., and Fischl, G. 1997. Diseases caused by Bipolaris sorokiniana and Drechslera tritici repentis in Hungary. Pages 80-88 in: Helminthosporium Blights of Wheat: Spot Blotch and Tan Spot. E. Duveiller, H. J. Dubin, J. Reeves, and A. McNab, eds. CIMMYT, Mexico, DF, Mexico.

Bankina, B., Bimšteine, G., Ruža, A., Priekule, I., Paura, L., Vaivade, I., and Fridmanis, D. 2013. Winter wheat crown and root rot are affected by soil tillage and crop rotation in Latvia. Acta Agric. Scand. B Soil Plant Sci. 63:723-730.

Bentley, A. R., Cromey, M. G., Farrokhi-Nejad, R., Leslie, J. F., Summerell, B. A., and Burgess, L. W. 2006. Fusarium crown and root rot pathogens associated with wheat and grass stem bases on the South Island of New Zealand. Australas. Plant Pathol. 35:495-502.

Berbee, M. L., Pirseyedi, M., and Hubbard, S. 1999. Cochliobolus phylogenetics and the origin of known, highly virulent pathogens, inferred from ITS and glyceraldehyde-3-phosphate dehydrogenase gene sequences. Mycologia 91: 964-977.

Bockus, W. W., Bowden, R. L., Hunger, R. M., Morrill, W. L., and Murray, T. D. 2010. Compendium of Wheat Diseases and Pests, 3rd ed. American Phytopathological Society, St. Paul, MN, U.S.A.

Broders, K. D., Parker, M. L., Melzer, M. S., and Boland, G. J. 2014. Phylogenetic diversity of Rhizoctonia solani associated with canola and wheat in Alberta, Manitoba, and Saskatchewan. Plant Dis. 98:1695-1701.

Brown, M. B., Woodhall, J., Mooney, S. J., and Ray, R. V. 2014. The occurrence and population dynamics of Rhizoctonia solani in soil of winter wheat. Pages 107-112 in: The Dundee Conference. Crop Protection in Northern Britain 2014, Dundee, U.K. 25-26 February 2014. The Association for Crop Protection in Northern Britain.

Burgess, L. W., Dodman, R. L., Pont, W., and Mayers, P. 1981. Fusarium diseases of wheat, maize and grain sorghum in eastern Australia. Pages 64-76 in: Fusarium: Diseases, Biology and Taxonomy. P. E. Nelson, T. A. Toussoun, and R. J. Cook, eds. Pennsylvania State University Press, University Park, PA, U.S.A.

Chen, C., Collins, D. J., and Morgan-Jones, G. 1996. Fungi associated with root rot of winter wheat in Alabama. J. Phytopathol. 144:193-196.

Cook, R. J. 1981. Fusarium diseases of wheat and other small grains in North America. Pages 39-52 in: Fusarium: Diseases, Biology, and Taxonomy. P. E. Nelson, T. A. Toussoun, and R. J. Cook, eds. The Pennsylvania State University Press, University Park, PA, U.S.A

Cook, R. J. 2010. Fusarium root, crown, and foot rots and associated seedling diseases. Pages 37-39 in: Compendium of Wheat Diseases and Pests, 3rd ed. W. W. Bockus, R. L. Bowden, R. M. Hunger, W. L. Morrill, T. D. Murray, and R. W. Smiley, eds. American Phytopathological Society, St. Paul, MN, U.S.A.
Cook, R. J., and Veseth, R. J. 1991. Wheat Health Management. American Phytopathological Society, St. Paul, MN, U.S.A.

Demirci, E. 1998. Rhizoctonia species and anastomosis groups isolated from barley and wheat in Erzurum, Turkey. Plant Pathol. 47:10-15.

Duczek, L. J., Verma, P. R., and Spurr, D. T. 1985. Effect of inoculum density of Cochliobolus sativus on common root rot of wheat and barley. Can. J. Plant Pathol. 7:382-386

Dyer, A. T., Johnston, R. H., Hogg, A. C., and Johnston, J. A. 2009. Comparison of pathogenicity of the Fusarium crown rot (FCR) complex (F. culmorum, $F$. pseudograminearum and $F$. graminearum) on hard red spring and durum wheat. Eur. J. Plant Pathol. 125:387-395.

Eken, C., Spanbayev, A., Tulegenova, Z., and Yechshzhanov, T. 2016. First report of Nigrospora oryzae on wheat in Kazakhstan. Plant Dis. 100:861.

Ellis, M. B. 1971. Dematiaceous Hyphomycetes. CAB, Kew, Surrey, U.K.

FAOSTAT. 2019. Food and Agriculture Organization Statistical Database. http:/ www.fao.org/faostat/en/\#data/QC

Fedel-Moen, R., and Harris, J. R. 1987. Stratified distribution of Fusarium and Bipolaris on wheat and barley with dryland root rot in South Australia. Plant Pathol. 36:447-454.

Fernandez, J. A., Wofford, D. S., and Horton, J. L. 1985. Interactive effects of freezing and common root rot fungi on winter wheat. Phytopathology 75:845-847.

Fernandez, M. R., and Chen, Y. 2005. Pathogenicity of Fusarium species on different plant parts of spring wheat under controlled conditions. Plant Dis. 89:164-169.

Fernandez, M. R., Fox, S. L., Hucl, P., Singh, A. K., and Stevenson, F. C. 2014 Root rot severity and fungal populations in spring common, durum and spelt wheat, and Kamut grown under organic management in western Canada. Can. J. Plant Sci. 94:937-946.

Fernandez, M. R., and Jefferson, P. G. 2004. Fungal populations in roots and crowns of common and durum wheat in Saskatchewan. Can. J. Plant Pathol. $26: 325-334$

Geiser, D. M., del Mar Jiménez-Gasco, M., Kang, S., Makalowska, I., Veeraraghavan, N., Ward, T. J., Zhang, N., Kuldau, G. A., and O'Donnell, K. 2004. FUSARIUM-ID v.1.0: A DNA sequence database for identifying Fusarium. Eur. J. Plant Pathol. 110:473-479.

Gonzalez, M. S., and Trevathan, L. E. 2000. Identity and pathogenicity of fungi associated with root and crown rot of soft red winter wheat grown on the upper coastal plain land resource area of Mississippi. J. Phytopathol. 148:77-85.

Hall, R., and Sutton, J. C. 1998. Relation of weather, crop, and soil variables to the prevalence, incidence, and severity of basal infections of winter wheat in Ontario. Can. J. Plant Pathol. 20:69-80.

Hernández-Restrepo, M., Madrid, H., Tan, Y. P., Da Cunha, K. C., Gene, J., Guarro, J., and Crous, P. W. 2018. Multi-locus phylogeny and taxonomy of Exserohilum. Persoonia 41:71-108.

Hill, J. P., Fernandez, J. A., and McShane, M. S. 1983. Fungi associated with common root rot of winter wheat in Colorado and Wyoming. Plant Dis. 67:795-797.

Jaaffar, A. K. M., Paulitz, T. C., Schroeder, K. L., Thomashow, L. S., and Weller, D. M. 2016. Molecular characterization, morphological characteristics, virulence, and geographic distribution of Rhizoctonia spp. in Washington State. Phytopathology 106:459-473.

Kosiak, B., Torp, M., Skjerve, E., and Thrane, U. 2003. The prevalence and distribution of Fusarium species in Norwegian cereals: A survey. Acta Agric Scand. B 53:168-176.

Kumar, S., Stecher, G., Li, M., Knyaz, C., and Tamura, K. 2018. MEGA X: Molecular evolutionary genetics analyses across computing platforms. Mol. Biol. Evol. 35:1547-1549.

Laraba, I., Keddad, A., Boureghda, H., Abdallah, N., Vaughan, M. M., Proctor, R. H., Busman, M., and O'Donnell, K. 2017. Fusarium algeriense, sp. nov., a novel toxigenic crown rot pathogen of durum wheat from Algeria is nested in the Fusarium burgessii species complex. Mycologia 109:935-950.

Ledingham, R. J., Atkinson, T. G., Horricks, J. S., Mills, J. T., Piening, L. J., and Tinline, R. D. 1973. Wheat losses due to common root rot in the prairie provinces of Canada, 1969-71. Can. Plant Dis. Surv. 53:113-122.

Leslie, J. F., and Summerell, B. A. 2006. The Fusarium Laboratory Manual Blackwell Publishing Ltd, Oxford, UK.

Lucas, P., Smiley, R. W., and Collins, H. P. 1993. Decline of Rhizoctonia root rot on wheat in soils infested with Rhizoctonia solani AG-8. Phytopathology 83:260-265.

MacNish, G. C. 1988. Changes in take-all (Gaeumannomyces graminis var. tritici), rhizoctonia root rot (Rhizoctonia solani) and soil $\mathrm{pH}$ in continuous wheat with annual applications of nitrogenous fertilizer in Western Australia. Aust. J. Exp. Agric. 28:333-341

Manamgoda, D. S., Cai, L., McKenzie, E. H. C., Crous, P. W., Madrid, H. Chukeatirote, E., Shivas, R. G., Tan, Y. P., and Hyde, K. D. 2012. A phylogenetic and taxonomic re-evaluation of the Bipolaris - Cochliobolus Curvularia complex. Fungal Divers. 56:131-144.

Matusinsky, P., Frei, P., Mikolasova, R., Svacinova, I., Tvaruzek, L., and Spitzer T. 2010. Species-specific detection of Bipolaris sorokiniana from wheat and barley tissues. Crop Prot. 29:1325-1330.

Mehdiyev, I. T. 2014. Identification of root rot diseases in winter wheat and investigation of their biological development characteristics. Pages 64-67 in: Book of Abstracts in Scientific Works of ASAU, Gəncə, Azerbaijan.

Morejon, K. R., Moraes, M. H. D., and Bach, E. E. 2006. Identification of Bipolaris bicolor and Bipolaris sorokiniana on wheat seeds (Triticum aestivum L.) in Brazil. Braz. J. Microbiol. 37:247-250. 
Moya-Elizondo, E., Arismendi, N., Castro, M. P., and Doussoulin, H. 2015. Distribution and prevalence of crown rot pathogens affecting wheat crops in southern Chile. Chil. J. Agric. Res. 75:78-84.

Moya-Elizondo, E. A., Rew, L. J., Jacobsen, B. J., Hogg, A. C., and Dyer, A. T. 2011. Distribution and prevalence of Fusarium crown rot and common root rot pathogens of wheat in Montana. Plant Dis. 95:1099-1108.

Nicholson, P., Simpson, D. R., Weston, G., Rezanoor, H. N., Lees, A. K., Parry, D. W., and Joyce, D. 1998. Detection and quantification of Fusarium culmorum and Fusarium graminearum in cereals using PCR assays. Physiol. Mol. Plant Pathol. 53:17-37.

O’Donnell, K., Cigelnik, E., and Nirenberg, H. I. 1998. Molecular systematics and phylogeography of the Gibberella fujikuroi species complex. Mycologia 90:465-493.

Ogoshi, A., Cook, R. J., and Bassett, E. N. 1990. Rhizoctonia species and anastomosis groups causing root rot of wheat and barley in the Pacific Northwest. Phytopathology 80:784-788.

Özer, G., Göre, M. E., Alkan, M., Yaman, T., and Dababat, A. A. 2019a. First report of Exserohilum pedicellatum causing root rot of wheat in Azerbaijan. Plant Dis. 103:1416.

Özer, G., Göre, M. E., Mustafa, İ., Khalilova, S., Muminjanov, H., and Dababat, A. A. 2019b. First report of Rhizoctonia solani AG-4 HGII and AG-2-1 causing root rot of wheat in Azerbaijan. Plant Dis. 103:2132.

Paulitz, T. C., Smiley, R. W., and Cook, R. J. 2002. Insights into the prevalence and management of soilborne cereal pathogens under direct seeding in the Pacific Northwest, USA. Can. J. Plant Pathol. 24:416-428.

Pettitt, T., Xu, X., and Parry, D. 2003. Association of Fusarium species in the wheat stem root complex. Eur. J. Plant Pathol. 109:769-774.

Poole, G. J., Smiley, R. W., Walker, C., Huggins, D., Rupp, R., Abatzoglou, J., Garland-Campbell, K., and Paulitz, T. C. 2013. Effect of climate on the distribution of Fusarium spp. causing crown rot of wheat in the Pacific Northwest of the United States. Phytopathology 103:1130-1140.

Rossi, V., Cervi, C., Chiusa, G., and Languasco, L. 1995. Fungi associated with foot rots on winter wheat in northwest Italy. J. Phytopathol. 143:115-119.

Sharon, M., Sneh, B., Kuninaga, S., Hyakumachi, M., and Naito, S. 2008. Classification of Rhizoctonia spp. using rDNA-ITS sequence analysis supports the genetic basis of the classical anastomosis grouping. Mycoscience 49:93-114.

Shikur Gebremariam, E., Dababat, A., Erginbas-Orakci, G., Karakaya, A., Sharma-Poudyal, D., and Paulitz, T. C. 2016. First report of Fusarium hostae causing crown rot of wheat (Triticum spp.) in Turkey. Plant Dis. 100:216.

Shikur Gebremariam, E., Sharma-Poudyal, D., Paulitz, T. C., Erginbas-Orakci, G., Karakaya, A., and Dababat, A. A. 2018. Identity and pathogenicity of Fusarium species associated with crown rot on wheat (Triticum spp.) in Turkey. Eur. J. Plant Pathol. 150:387-399.

Sivanesan, A. 1987. Graminicolous Species of Bipolaris, Curvularia, Drechslera, Exserohilum and Their Teleomorphs. Mycological Papers 158. CAB International, Wallingford, U.K.
Smiley, R. W., Gourlie, J. A., Easley, S. A., Patterson, L. M., and Whittaker, R. G. 2005. Crop damage estimates for crown rot of wheat and barley in the Pacific Northwest. Plant Dis. 89:595-604.

Smiley, R. W., and Patterson, L. M. 1996. Pathogenic fungi associated with Fusarium foot rot of winter wheat in the semiarid Pacific Northwest. Plant Dis. 80:944-949.

Specht, L. P., and Rush, C. M. 1988. Fungi associated with root and foot rot of winter wheat and populations of Cochliobolus sativus in the Texas Panhandle. Plant Dis. 72:959-963.

Strausbaugh, C. A., Bradley, C. A., Koehn, A. C., and Forster, R. L. 2004. Survey of root diseases of wheat and barley in southeastern Idaho. Can. J. Plant Pathol. 26:167-176.

Tamura, K., and Nei, M. 1993. Estimation of the number of nucleotide substitutions in the control region of mitochondrial DNA in humans and chimpanzees. Mol. Biol. Evol. 10:512-526.

Thompson, J. D., Higgins, D. G., and Gibson, T. J. 1994. CLUSTAL W: Improving the sensitivity of progressive multiple sequence alignment through sequence weighting, position-specific gap penalties and weight matrix choice. Nucleic Acids Res. 22:4673-4680.

Tunali, B., Nicol, J. M., Hodson, D., Uckun, Z., Büyük, O., Erdurmuş, D., and Bağci, S. A. 2008. Root and crown rot fungi associated with spring, facultative, and winter wheat in Turkey. Plant Dis. 92:1299-1306.

Ünal, F., Bayraktar, H., Yıldırım, A. F., Akan, K., and Dolar, F. S. 2015. Determination of Rhizoctonia species and anastomosis groups in wheat production areas in Kayseri, Kırşehir, Nevşehir and Aksaray provinces. Plant Prot. Bull. 55:107-122.

Wang, M., Liu, F., Crous, P. W., and Cai, L. 2017. Phylogenetic reassessment of Nigrospora: Ubiquitous endophytes, plant and human pathogens. Persoonia 39: 118-142.

White, T. T., Bruns, T., Lee, S., and Taylor, J. 1990. Amplification and direct sequencing of fungal ribosomal RNA genes for phylogenetics. Pages 315-322 in: PCR Protocols: A Guide to Methods and Applications. M. A. Innis, D. H. Gelfand, J. J. Sninsky, and T. J. White, eds. Academic Press, San Diego, CA, U.S.A.

Wildermuth, G. B., Tinline, R. D., and McNamara, R. B. 1992. Assessment of yield loss caused by common root rot in wheat cultivars in Queensland. Aust. J. Agric. Res. 43:43-58

Xu, F., Yang, G., Wang, J., Song, Y., Liu, L., Zhao, K., and Han, Z. 2018. Spatial distribution of root and crown rot fungi associated with winter wheat in the North China Plain and its relationship with climate variables. Front. Microbiol. 9:1054.

Yin, C., Hulbert, S. H., Schroeder, K. L., Mavrodi, O., Mavrodi, D., Dhingara, A., Schillinger, W. F., and Paultiz, T. C. 2013. Role of bacterial communities in the natural suppression of Rhizoctonia solani bare patch disease of wheat (Triticum aestivum L.). Appl. Environ. Microbiol. 79:7428-7438. 